\title{
Uji Efektivitas Antifungi Perasan Daun Turi (Sesbania grandiflora (L.) Pers.) terhadap Jamur Candida albicans
}

\section{The Antifungal Activity of Hummingbird tree (Sesbania grandiflora (L.) Pers.) Leaves Extract against Candida albicans}

\author{
Inur Tivani*, Wilda Amananti \\ DIII Farmasi Politeknik Harapan Bersama \\ Jl. Mataram No. 9 Pesurungan Lor Kota Tegal Jawa Tengah, Indonesia \\ *Corresponding author email: tiva.nie40@gmail.com
}

Received 12-11-2019

Accepted 03-04-2020

Available online 01-07-2020

\begin{abstract}
ABSTRAK
Penyebab keputihan salah satunya yaitu jamur Candida albicans. Daun turi (Sesbania grandiflora (L.) Pers.) memiliki kandungan saponin yang lebih tinggi dibandingkan dengan bagian tangkai dan bijinya. Saponin dikenal sebagai antibakteri dan antimikroba. Tujuan dari penelitian ini yaitu untuk mengetahui pada konsentrasi berapa perasan daun turi paling efektif untuk menghambat pertumbuhan jamur Candida albicans. Populasi dalam penelitian ini adalah daun turi yang diambil dari persawahan daerah Talang. Daun turi yang diperoleh selanjutnya dibuat perasan dengan cara memeras daun tersebut menggunakan blender agar diperoleh air kemudian diencerkan dengan menggunakan akuades. Perasan daun turi dibuat dengan konsentrasi 5, 15, dan 25\%. Medium pembiakan jamur Candida albicans menggunakan media Potato Dextrose Agar (PDA). Penelitian ini menggunakan dua medium PDA yaitu medium padat dan medium cair. Uji efektivitas antifungi menggunakan metode difusi sumuran. Dari hasil penelitian menunjukkan bahwa perasan daun turi dengan konsentrasi $5 \%$ memiliki luas daerah hambat sebesar $94,16 \pm 56,37 \mathrm{~mm}^{2}$, konsentrasi $15 \%$ memiliki luas daerah hambat $227,24 \pm 101,91 \mathrm{~mm}^{2}$, sedangkan perasan daun turi $25 \%$ memiliki luas daerah hambat $329,94 \pm 133,52 \mathrm{~mm}^{2}$. Dari penelitian tersebut dapat disimpulkan bahwa perasan daun turi yang paling efektif untuk menghambat pertumbuhan jamur Candida albicans yaitu perasan daun turi dengan konsentrasi $25 \%$.
\end{abstract}

Kata kunci: antifungi, Candida albicans, perasan daun turi.

\section{ABSTRACT}

One of the causes of vaginal discharge is the fungus Candida albicans. Turi leaves contain higher saponins than those in the stems and seeds of the turi plant. Saponins 
are known as antibacterial and antimicrobial. The purpose of this study is to determine at what concentration of turi leaves are most effective to inhibit the growth of the fungus Candida albicans. The population in this study is the turi leaves taken from rice fields in the Talang area. The turi leaves obtained are then squeezed by squeezing the leaves using a blender to obtain water and then diluted using distilled water. The juice of turi leaves is made with a concentration of 5, 15, and 25\%. Candida albicans mushroom culture medium uses Potato Dextrose Agar (PDA) media. This research uses two PDA media, they are solid and liquid medium. Antifungal effectiveness test uses the well diffusion method. The results showed that the turi leaf extract with a concentration of $5 \%$ had an inhibitory area of $94.16 \pm 56.37 \mathrm{~mm}^{2}$, the concentration of $15 \%$ had an inhibitory area $227.24 \pm 101.91 \mathrm{~mm}^{2}$ while the turi leaf extract $25 \%$ had an inhibitory area $329.94 \pm 133.52 \mathrm{~mm}^{2}$. From these studies it can be concluded that the extract of turi leaves is the most effective way to inhibit the growth of the fungus Candida albicans, which is turi leaf extract with a concentration of $25 \%$.

Key words: antifungal, Candida albicans, turi leaf extract.

\section{Pendahuluan}

Di Indonesia akhir-akhir ini mengalami perubahan cuaca. Musim kemarau lebih panjang dibandingkan dengan musim penghujan. Hal ini berdampak pada produksi keringat yang berlebih. Bagi kaum wanita, jika kurang menjaga kebersihan di cuaca yang lebih banyak kemarau atau dengan kata lain panas, akan berakibat pada keputihan di area kewanitaan.

Flour albus atau dikenal dengan istilah keputihan sering terjadi pada wanita. Menurut WHO, Infeksi pada vagina setiap tahunnya menyerang perempuan di seluruh dunia sebesar $10-$ 15\% dari 100 juta perempuan. Contohnya, remaja yang terkena infeksi jamur kandida sekitar $15 \%$ dan mengalami keputihan.

Penyebab keputihan salah satunya yaitu jamur Candida albicans. Secara alamiah, keputihan normal terjadi ketika menjelang atau sesudah menstruasi. Namun jika kurangnya menjaga kebersihan di area kewanitaan atau stress dapat memicu timbulnya penyakit ini. Apabila keputihan tidak normal (patologis) dibiarkan saja tanpa diobati atau dengan kata lain tidak segera diberikan penanganan, akibatnya infeksi bisa menjalar masuk ke dalam rahim sampai menginfeksi ovarium. Oleh sebab itu, penderita perlu memeriksakan organ dan saluran reproduksi ke pelayanan kesehatan agar diketahui penyebab patologisnya untuk dilakukan pencegahan serta penanganan yang tepat (Solikhah et al., 2010).

Berdasarkan penelitian Abrori et al. (2017) menyebutkan bahwa salah satu faktor yang menyebabkan keputihan antara lain yaitu penggunaan pembersih vagina. Di pasaran banyak beredar obat untuk mengatasi keputihan. Namun, masyarakat sekarang lebih memilih untuk pengobatan herbal dibandingkan dengan pengobatan kimiawi. Salah satu 
solusi dari permasalahan ini yaitu dengan pengobatan alami menggunakan bahan alami salah satunya yaitu daun turi.

Berdasarkan hasil penelitian yang dilakukan oleh Amananti et al. (2017) menyebutkan bahwa pada daun turi terdapat kandungan saponin yang lebih tinggi dibandingkan pada tangkai dan biji tanaman turi. Saponin dikenal sebagai antibakteri dan antimikroba. Dalimartha (2009) juga menyebutkan bahwa daun turi memiliki kandungan saponin tanin, glikoside, peroksidase, vitamin A dan B. Daun turi memiliki khasiat yang dapat digunakan untuk mengatasi penyakit keputihan (Widyaningrum, 2011).

Daun turi memiliki zat antimikroba salah satunya yaitu saponin. Guna mendapatkan saponin maka akan dibuat perasan dari daun turi. Tujuan dari penelitian ini yaitu untuk mengetahui pada konsentrasi berapa perasan daun turi paling efektif untuk menghambat pertumbuhan jamur Candida albicans.

\section{Metode Penelitian}

\section{Alat dan Bahan}

Alat-alat yang digunakan dalam penelitian ini antara lain: tabung reaksi, Erlenmeyer, corong kaca, gelas ukur, dan cawan petri dari Iwaki Pyrex ${ }^{\circledast}$. Beaker glass, autoklaf $\left(\mathrm{HL} 36 \mathrm{Ac} \mathrm{C}^{\circledast}\right)$, alumunium foil, kertas saring Whatman, jangka sorong, tip dan mikropipet (Acura ${ }^{\circledR}$ ), jarum ose, inkubator (Memmert $\left.{ }^{\circledR}\right)$, dan Laminar Air Flow (LAF). Sedangkan bahan-bahan yang digunakan dalam penelitian ini antara lain daun turi yang diambil dari persawahan daerah Talang, $\mathrm{NaCl}$, akuades, kentang, dekstrosa, agaragar, etanol 70\%, dan Candida albicans ATCC 10231.

\section{Jalannya Penelitian}

1. Sterilisasi alat dan bahan

Sterilisasi dilakukan pada alatalat dan medium. Dalam penelitian ini, alat yang digunakan yaitu autoklaf dengan kondisi suhu $121{ }^{\circ} \mathrm{C}$ selama 15 menit.

2. Pembuatan perasan daun turi

Pembuatan perasan daun turi dilakukan dengan cara memilih daun turi yang segar dengan berat 100 gram. Daun turi dibersihkan dengan air mengalir lalu dimasukkan ke dalam blender hingga halus. Air perasan kemudian disaring menggunakan kain dan kertas saring yang telah disterilkan (Hasbi, 2012). Perasan daun turi yang digunakan dibagi menjadi 3 konsentrasi yaitu konsentrasi 5, 15, dan 25\%. Perasan daun turi konsentrasi $5 \%$ diperoleh dengan melarutkan $1 \mathrm{~mL}$ perasan daun turi kemudian ditambahkan akuades sampai volume $20 \mathrm{~mL}$.

3. Pembuatan medium PDA

Medium pembiakan jamur Candida albicans menggunakan media Potato Dextrose Agar (PDA). Pada penelitian ini digunakan dua medium PDA yaitu medium PDA padat dan medium PDA cair. Media PDA padat dibuat dari $100 \mathrm{~g}$ kentang dalam $500 \mathrm{~mL}$ akuades, dididihkan sampai volumenya menjadi setengah dari volume awal. Larutan ini 
kemudian diangkat dan disaring menggunakan kertas saring ke dalam Erlenmeyer. Hasil penyaringan kemudian ditambahkan $30 \mathrm{~g}$ dextrose; 7,5 g agar, dan sisa akuades sampai volumenya $500 \mathrm{~mL}$, dipanaskan kembali hingga mendidih dan homogen. Larutan kemudian diangkat dan dicek pHnya. Sebanyak $30 \mathrm{~mL}$ PDA padat dituangkan pada masing-masing cawan petri. Media PDA cair dibuat sama persis seperti PDA padat namun tidak ditambakan agar. PDA cair dimasukkan ke dalam tabung reaksi, selanjunya ujung dari tabung reaksi ditutup denan kapas. PDA padat dan PDA cair selanjutnya di sterilkan ke dalam autoklaf pada suhu $121{ }^{\circ} \mathrm{C}$ selama 15 menit.

4. Pembuatan biakan jamur Candida albicans

Pembuatan biakan jamur dilakukan dengan mengambil dua ose koloni Candida albicans dari medium induk dan ditanam pada medium cair PDA, dibuat garis dengan menarik dari dasar tabung lurus ke atas. Setelah itu media diinkubasi dengan suhu $25{ }^{0} \mathrm{C}$ selama 5 hari. Proses pembuatan biakan jamur dilakukan pada ruang inkas secara aseptik (usaha mempertahankan objek agar bebas dari mikroorganisme) dengan lampu spiritus dan menggunakan masker serta sarung tangan.

5. Uji aktivitas antijamur

Pada penelitian ini pengujian pertumbuhan jamur dilakukan dengan menggunakan metode difusi cetak lubang atau sumuran. Biakan jamur Candida albicans diinokulasi menggunakan kapas lidi steril, dengan cara olesan di permukaan media padat PDA pada cawan petri, dibuat 5 lubang sumuran menggunakan boorprof dengan diameter $6 \mathrm{~mm}$ pada media padat PDA (3 untuk ekstrak, 1 untuk kontrol negatif menggunakan akuades steril, dan 1 kontrol positif menggunakan ketoconazole 25\%). Perasan daun turi sebanyak $50 \mu \mathrm{ll}$ diteteskan menggunakan mikropipet dengan konsentrasi masing-masing 5, 15, dan $25 \%), 50 \mu \mathrm{L}$ kontrol negatif, dan $50 \mu \mathrm{l}$ kontrol positif. Selanjutnya bahan uji diinkubasi dengan suhu $25{ }^{\circ} \mathrm{C}$ selama 5 hari dan perubahan yang terjadi diamati dan diukur diameter zona bening di sekitar sumuran. Pembacaan daerah hambat dari perasan daun turi dilakukan dengan mengukur diameter sumuran dan diameter total di sekitar lubang dengan menggunakan jangka sorong. Data diameter yang diperoleh kemudian dikonversikan ke dalam luas dengan menggunakan rumus luas lingkaran yaitu $L=\pi r^{2}$, dengan $\pi=3,14$ dan $r$ (jari-jari) $=1 / 2$ diameter, sehingga akan diperoleh luas total dan luas sumuran. Luas daerah hambat diperoleh dari luas total dikurangi luas sumuran.

\section{Hasil dan Pembahasan}

Tabel 1 menunjukkan luas daerah hambat perasan daun turi terhadap jamur Candida albicans. Dari tabel tersebut terlihat bahwa luas 
daerah yang terbentuk untuk perasan daun turi, maka zona hambat di konsentrasi 5, 15, dan 25\% berturutsekitar sumuran semakin besar, artinya turut sebesar 94,16 $\pm 56,37$; luas daya hambat semakin luas. Hal $227,24 \pm 101,91 ; \quad$ dan $329,94 \pm 133,52$ tersebut disebabkan karena semakin $\mathrm{mm}^{2}$. Hasil tersebut menunjukkan besar konsentrasi berarti semakin bahwa semakin tinggi konsentrasi banyak kandungan saponin dalam perasan daun turi maka luas daerah perasan daun turi tersebut. Namun, luas hambat jamur Candida albicans semakin daerah hambat perasan daun turi masih besar. Luas daerah hambat yang telah dihitung dengan nyata terlihat ditandai jauh jika dibandingkan dengan luas daerah hambat dari hasil kontrol positif denan luasnya zona bening di sekitar menggunakan ketokonazol $25 \%$.

sumuran. Semakin tinggi konsetrasi

Tabel 1. Luas daerah hambat perasan daun turi terhadap Candida albicans

\begin{tabular}{ccccc}
\hline $\begin{array}{c}\text { Konsentrasi } \\
\text { (\%) }\end{array}$ & \multicolumn{3}{c}{ Luas Daya Hambat $\left(\mathbf{m m}^{\mathbf{2}}\right)$} & Rata-Rata \pm Standar deviasi \\
\hline $\mathbf{5}$ & 153,11 & $\mathbf{n ~ 2}$ & $\mathbf{n ~ 3}$ & \\
$\mathbf{1 5}$ & 298,43 & 110,62 & 88,58 & $94,16 \pm 56,37$ \\
$\mathbf{2 5}$ & 446,79 & 184,42 & 358,62 & $227,24 \pm 101,91$ \\
$\mathbf{( + )}$ & 650,26 & 394,26 & 561,09 & $329,94 \pm 133,52$ \\
$(-)$ & 0 & 0 & 0 & $535,21 \pm 129,95$ \\
\hline
\end{tabular}

Saponin memiliki efek antibakteri dan antijamur. Saponin berkontribusi sebagai antijamur dengan mekanisme menurunkan tegangan permukaan membran sterol dari dinding sel Candida albicans, sehingga permeabilitas membran meningkat. Permeabilitas yang meningkat mengakibatkan cairan intraseluler yang lebih pekat tertarik keluar sel sehingga nutrisi, zat-zat metabolisme, enzim, dan protein dalam sel keluar, dan jamur mengalami kematian. Saponin merupakan golongan senyawa yang dapat menghambat atau membunuh mikroba dengan cara berinteraksi dengan membran sterol. Efek utama saponin terhadap mikroba adalah adanya pelepasan protein dan enzim dari dalam sel (Septiadi et al., 2013).

Sifat antijamur saponin berasal dari pembentukan ikatan senyawa polar saponin dengan lipoprotein dan ikatan gugus nonpolar saponin dengan lemak membran plasma sel jamur. Ikatan tersebut menyebabkan lemak pecah dan terjadi penimbunan dan menyebabkan terganggunya permeabilitas membran sel jamur. Hal tersebut menyebabkan lisisnya sel Candida albicans dan akhirnya menyebabkan kematian sel jamur (Kurniawati et al., 2016).

\section{Simpulan}

Konsentrasi $25 \%$ perasan

daun turi paling efektif untuk 
menghambat pertumbuhan jamur Candida albican.

\section{Daftar Pustaka}

Abrori, Hernawan, A.D., Ermulyadi. 2017. Faktor yang berhubungan dengan kejadian keputihan patologis siswi SMAN 1 Simpang Hilir Kabupaten Kayong Utara. Unnes Journal of Public Health, 6(1):24-34.

Dalimartha, S. 2009. Atlas Tumbuhan Obat Indonesia. Jilid 1. Jakarta: Trubus Agriwidya.

Hasbi, S. 2012. Uji sensitivitas perasan daun alpokat (Persea mericana miller) terhadap Pseudomonas sp. metode in vitro. Karya Tulis Ilmiah. Banda Aceh: Akademi Analis Kesehatan.

Kurniawati, A., Mashartini, A., Fauzia, I.S. 2016. Perbedaan khasiat anti jamur antara ekstrak etanol daun kersen (Muntingia calabura L.) dengan nistatin terhadap pertumbuhan Candida albicans. Jurnal PDGI, 65(3):7477.
Septiadi, T., Pringgenies, D., Radjasa, O.K. 2013. Fitokimia dan aktivitas antijamur ekstrak teripang keling (Holoturia atra) dari Pantai Bandengan Jepara terhadap jamur Candida albicans. Journal of Marine Research, 37(5):304-306.

Solikhah, R., Marsito, Nurlaila. 2010. Hubungan tingkat pengetahuan tentang keputihan dengan perilaku remaja putri dalam menjaga kebersihan diri di Desa Bandung Kecamatan Kebumen Kabupaten Kebumen. Jurnal IImiah Kesehatan Keperawatan, 6(2):63-70.

Widyaningrum, H. 2011. Kitab Tanaman Obat Nusantara. Yogyakarta: Media Pressindo

Amananti, W., Tivani, I., Riyanta, A.B. 2017. Uji kandungan saponin daun, tangkai, dan biji tanaman turi (Sesbania grandiflora). Prosiding $2^{\text {nd }}$ Seminar Nasional Iptek Terapan (SENIT), 209-213. 15-17 Mei 2017, TegalIndonesia. 